\title{
A Quantitative Assay of Puccinia coronata f. sp. avenae DNA in Avena sativa
}

\author{
E. W. Jackson, J. B. Avant, K. E. Overturf, and J. M. Bonman, USDA ARS Small Grains and Potato Germplasm \\ Research Unit, 1691 S. 2700 W., Aberdeen, ID 83210
}

\begin{abstract}
Jackson, E. W., Avant, J. B., Overturf, K. E., and Bonman, J. M. 2006. A quantitative assay of Puccinia coronata f. sp. avenae DNA in Avena sativa. Plant Dis. 90:629-636.

Crown rust, caused by Puccinia coronata f. sp. avenae, is the most damaging disease of oat. Quantification of the disease can be done by visual or digital assessments of diseased leaf area, lesion number, lesion size, and latent period. Laborious measurements of sporulation can also be made. As an alternative to these methods, a new quantitative assay was developed. The method employs simple inoculum application, quantitative sampling from inoculated areas, a closed tube DNA extraction method restricting loss of tissue, and real-time polymerase chain reaction (PCR) using a pathogen-specific TaqMan primers/probe set. Image analyses of genotypes with varying levels of crown rust resistance were compared to fungal DNA (FDNA) estimations by the new assay. The moderately resistant genotype IA98822-2 was distinguished from susceptible genotypes at the seedling stage, and the moderately resistant genotype $\mathrm{O} \times \mathrm{T} 107$ was distinguished from the resistant cultivar TAM-O-301 at seedling and adult plant stages using FDNA. These separations were not evident with digital image analysis. The new assay also detected fungal development earlier and more rapidly in genotypes with lower levels of resistance. The assay can consistently estimate disease and should be useful for studying many aspects of the crown rust host-pathogen interaction where precise assessment of pathogen development is needed.
\end{abstract}

Accurate disease assessment is a prerequisite for the study of host resistance and other aspects of a host-pathogen interaction. Historically, qualitative assessment of cereal rust diseases has been based on visual scoring of rust "infection types", which requires skill and experience (30). Quantitative assessment has been based either on laborious measurement of resistance components such as latent period, pustule size and density, and sporulation capacity $(10,18,21-23,29)$ or on visual estimation of percent diseased leaf area (33). For visual assessments, several diagrammatic scales have been developed as reference tools to standardize disease ratings (24), and these have been widely applied, especially in field studies. One major disadvantage of visual assessment, however, is that it relies on the expertise of the rater, making it subject to bias. Studies on the inter-rater reliability using visual disease assessments of dollar spot on bentgrass by Nutter et al. (20) showed significant differences in results among raters. To

Corresponding author: E. W. Jackson

E-mail: ejackson@uidaho.edu

* The $\boldsymbol{e}$-Xtra logo stands for "electronic extra" and indicates that Figure 1 appears in color in the online edition.

Accepted for publication 26 December 2005.

DOI: 10.1094/PD-90-0629

This article is in the public domain and not copyrightable. It may be freely reprinted with customary crediting of the source. The American Phytopathological Society, 2006. eliminate inconsistencies produced by rater bias, the use of digital image analysis has been examined $(8,27)$. Assessments of partial resistance components using digital analyses by Diaz-Lago et al. (8) effectively estimated resistance components and appeared to be an improvement over visual ratings. One limitation of digital assessment, however, is that color contrast between diseased and healthy tissue must be distinguishable.

Convenient and precise measurement of pathogen DNA associated with the host would provide a new means of assessing disease resistance. Real-time polymerase chain reaction (PCR) is an accurate and sensitive tool to identify and quantify fungal pathogens within host tissues (13), but it has not previously been applied to the study of disease resistance in cereal rusts. Quantification of pathogens using realtime PCR is based on cycle by cycle detection of amplified pathogen-specific DNA sequences via fluorescence. The fluorescence is generated by cleavage of quencher dyes which suppress a fluorescing reporter dye (16). In the case of TaqMan technology, the quencher and reporter dyes are attached to a probe that is complementary to the pathogen's DNA template. During PCR, (i) the probe anneals with the template DNA between the pathogen specific binding sites and (ii) the reporter and quencher are separated resulting in fluorescence. The cycle in which the fluorescence is first detected above the background is known as the cycle threshold $\mathrm{Ct}$ ) value. This value is inversely proportional to the amount of targeted template
DNA within each reaction and has been shown to be a reliable measurement by real-time PCR to detect and quantify DNA (12). Ct values can thus be used to quantify fungal DNA (FDNA) within host tissues if the TaqMan primers/probe set is specific to pathogen DNA. Using a set of standards, $\mathrm{Ct}$ values are converted into DNA amounts. This technique has been used to develop quantitative real-time PCR (QPCR) assays for several diseases including rice blast, sudden death syndrome of soybean, late blight of potato and tomato, and leaf stripe and net blotch of barley $(2,9,15,28)$. These QPCR assays have been focused on optimization of the real-time PCR protocol and use conventional methods for inoculation, sampling, and DNA extraction that have not necessarily been optimized for highly sensitive pathogenspecific molecular assays.

Data from highly sensitive molecular assays could be influenced by inconsistent disease development on or within targeted leaf segments. One factor that can influence disease development is the initial amount and uniformity of inoculum applied to the area. Several good techniques have been developed using special instrumentation for uniform and quantitative rust pathogen inoculations $(1,7,31)$. Direct application of spores in a water-based carrier to targeted leaf segments may be an alternative to techniques requiring special instruments, which might not be readily available. Good assurance of disease pressure and uniform infection of leaves has been demonstrated by the use of cotton swabs to apply inoculum in a detached leaf assay (14). Additionally, Brodny et al. (6) tested disease reactions of three races on a single leaf using direct application by cotton swabs. To date, no studies have compared the effect of hand held oil-based spray inoculation to water-based swab inoculation on disease development of specific leaf segments.

Crown rust, caused by Puccinia coronata $\mathrm{f}$. sp. avenae, is the most damaging disease of cultivated oat (Avena sativa L.), reducing grain yield and quality wherever oat is grown $(19,33)$. The objective of this research was to develop an assay to measure $P$. coronata infection in oat. This was done by using direct application of inoculum, quantitative sampling from inoculated areas, a closed tube DNA extraction method that restricts loss of tissue, and real-time PCR with a pathogen-specific TaqMan primers/probe set to estimate FDNA within infected tissues. Using geno- 
types with varying levels of crown rust resistance, we compared results from the new assay with digital assessments of disease. Also, fungal development within host tissues over time was studied.

\section{MATERIALS AND METHODS}

Fungal isolates. The isolates used in this study were single-pustule cultures obtained from the USDA-ARS Cereal Disease Laboratory (CDL), St. Paul, MN (P. coronata isolates 98MNB245, TX 030, MN111, 03CA075-1, and FL 072, and $P$. graminis f. sp. avenae isolate TLB 27) and the USDA-ARS Northern Plains Area, Grain Marketing and Production Research Center, Manhattan, KS ( $P$. triticina isolate PRTUS25). The isolate used for inoculation studies and genotype testing, $98 \mathrm{MNB} 245$, was increased by inoculating the oat cultivar Brooks and collecting urediniospores from a single pustule as soon as sporulation occurred. These urediniospores were dried and stored at $-80^{\circ} \mathrm{C}$ in cryovials for future use. For primer/probe specificity testing, the additional $P$. coronata isolates TX 030, MN111, 03CA075-1, and FL 072, the $P$. graminis isolate, and the $P$. triticina isolate were also used. Studies were conducted under Animal and Plant Health Inspection Service permit numbers 64356, 69711, and 70055.

Plant materials. Five oat genotypes (treatments) were selected based on their reactions to isolate $98 \mathrm{MNB} 245$ in preliminary greenhouse tests. The genotypes were characterized into three groups: susceptible ('Provena' and 'Ogle'), moderately resistant (IA 98822-2 and $\mathrm{O} \times \mathrm{T}$ 107), and resistant ('TAM-O-301'). Provena, Ogle, and TAM-O-301 are cultivars, IA98822-2 is a breeding line from Iowa State University that has shown intermediate resistance to crown rust in multiple location trials (3), and $\mathrm{O} \times \mathrm{T} 107$ is a recombinant inbred line from an Ogle $\times$ TAM-O-301 mapping population (26).

Four seed of each genotype tested were planted in five $15-\mathrm{cm}$-diameter pots (replicates) containing a 1:2:1 (vol/vol/vol) mix of sand, peat moss, and vermiculite. After emergence, seedlings were thinned so that a single seedling of each genotype remained per pot. Pots were placed in the greenhouse with a 14 - to $15-\mathrm{h}$ photoperiod at 13 to $21^{\circ} \mathrm{C}$ until seedlings were at the second leaf stage for primary leaf studies, fifth leaf stage for time course studies, and heading stage for flag leaf studies.

Inoculum production and application studies. For inoculum increase, urediniospores stored at $-80^{\circ} \mathrm{C}$ were recovered. The spores were suspended in $45^{\circ} \mathrm{C}$ Soltrol 170 (Isoparaffin) and maintained for $5 \mathrm{~min}$ in a water bath. After incubation, the suspension was sprayed onto the susceptible cultivar Provena. The plants were allowed to dry and then placed in a dew chamber at $21^{\circ} \mathrm{C}$ in the dark for $21 \mathrm{~h}(25,32)$. Plants were then moved to a growth chamber programmed for $13 \mathrm{~h}$ light at $25^{\circ} \mathrm{C}$ and 11 $\mathrm{h}$ darkness at $18^{\circ} \mathrm{C}$.

Two independent experiments based on diseased leaf area (DLA) of targeted leaf segments were done to evaluate the consistency of hand held spray inoculation and direct swab inoculation. Fresh urediniospores were collected from inoculated Provena plants 3 to 6 days after initial sporulation using a vacuum collector. An oil-based medium was prepared for spray inoculations by adding approximately 8 $\mathrm{mg}$ of fresh spores to $4 \mathrm{ml}$ of Soltrol 170 (Isoparaffin) and agitating the resulting suspension. A water-base medium was prepared for swab inoculations by adding approximately $8 \mathrm{mg}$ of fresh spores to $2 \mathrm{ml}$ of sterile $\mathrm{ddH}_{2} \mathrm{O}$ with $0.3 \%$ gelatin and $0.3 \%$ Tween 20 . The mixture was vigorously agitated and poured through cheesecloth, and $2 \mathrm{ml}$ of sterile $\mathrm{ddH}_{2} \mathrm{O}$ was added. The concentration of each suspension was measured using a hemacytometer and diluted to approximately $2.5 \times 10^{5}$ urediniospores $/ \mathrm{ml}$.

To compare inoculation methods, primary leaves of the susceptible Provena, the moderately resistant IA 98822-2, and the resistant TAM-O-301 were spray or swab inoculated in each experiment, with six replications each. For hand held spray inoculations, entire primary leaves were inoculated with the oil-based suspension using a spray atomizer held at a distance of approximately $60 \mathrm{~cm}$. Swab inoculations were done by applying the water-based suspension directly to both surfaces of a 5 $\mathrm{cm}^{2}$ leaf section using a sterile polyester fiber-tipped applicator swab (Falcon). After inoculation, genotypes were completely randomized and incubated in dew and growth chambers as described previously. Ten days after inoculation, leaves were harvested and scanned at 118 dots per $\mathrm{cm}$ for digital analysis. Diseased leaf area (DLA), including pustules and a portion of the chlorotic area based on threshold settings of 103 and 60, was measured on 4.8 $\mathrm{cm}^{2}$ sections from the center of each leaf for spray inoculations and the inoculated area of each leaf for swab inoculations using the Assess imaging analysis software (17). Multiple mean comparisons were done for each experiment using the TukeyKramer HSD test $(P=0.05)$, and standard deviations were calculated (JMP, SAS Institute, Cary, NC).

DNA extraction and amplification. Standardized weights $\left(10^{5}, 10^{4}, 10^{3}\right.$, and $10^{2} \mu \mathrm{g}$ ) of urediniospores or sections of infected leaf tissue were placed in $1.5-\mathrm{ml}$ tubes (Qiagen, cat. no. 19560) and lyophilized. Approximately $30 \mathrm{mg}$ of $0.1-\mathrm{mm}$ diameter zirconia/silica beads (Biospec cat. no. $11079101 \mathrm{z}$ ) and $100 \mathrm{mg}$ of 0.5 mm-diameter zirconia/silica beads (Biospec cat. no. $11079105 \mathrm{z}$ ) were added to each tube. For DNA extractions from infected leaf tissues, an additional 3.2-mm stainless steel bead (Biospec cat. no. 11079132ss) and a 2.3-mm stainless steel bead (Biospec cat. no. 11079123ss) were added. Tissues were ground on a vibration mill (Retsch MM 300 USA) for $30 \mathrm{~min}$ at $30 \mathrm{~Hz}$ (30 oscillations/s). After grinding, the tubes were centrifuged at approximately $6,000 \times g$ for $10 \mathrm{~min}$, and $500 \mu \mathrm{l}$ of CTAB extraction buffer $\left(18^{\circ} \mathrm{C}\right)$ was mixed with each sample. Samples were further ground for $15 \mathrm{~min}$ on the vibration mill, then placed in a water bath at $65^{\circ} \mathrm{C}$ for 25 min. Chloroform:isoamyl alcohol (24:1) was added, and after a 15-min centrifugation at approximately $6,000 \times g$, the supernatant was collected and DNA was precipitated with isopropanol. DNA samples were then washed with $70 \%$ ethanol and dissolved in $200 \mu$ l of TE buffer containing 10 $\mu \mathrm{g} \mathrm{ml} \mathrm{m}^{-1}$ RNase. The quantity and quality were measured using absorption at $A_{260 \mathrm{~nm}}$ and $A_{280 \mathrm{~nm}}$ with a spectrophotometer, and samples were stored at $4^{\circ} \mathrm{C}$.

Conventional PCR amplifications were run at $50^{\circ} \mathrm{C}$ for $60 \mathrm{~s}$ and $95^{\circ} \mathrm{C}$ for $10 \mathrm{~min}$, then 40 cycles at $95^{\circ} \mathrm{C}$ for $15 \mathrm{~s}$ and $60^{\circ} \mathrm{C}$ for $60 \mathrm{~s}$ in a total volume $50 \mu \mathrm{l}$ containing: $28.6 \mu$ sterile $\mathrm{ddH}_{2} \mathrm{O}, 5.0 \mu \mathrm{l} 10 \times$ buffer, $3.0 \mu \mathrm{l} 25 \mathrm{mM} \mathrm{Mg}{ }^{2+}, 0.4 \mu \mathrm{l} 5 \mathrm{U} / \mu \mathrm{l}$ AmpliTaq DNA polymerase (Applied Biosystems, cat. no. N808-0167), $1.0 \mu \mathrm{l} 10 \mathrm{mM}$ dNTPs, $1.0 \mu \mathrm{l}$ of each forward and reverse primer $(300 \mathrm{nM})$, and $10 \mu \mathrm{l}$ DNA template (20 ng/ $\mu \mathrm{l})$. The PCR products were visualized on $2 \%$ agarose (SIGMA) gels stained with ethidium bromide after $2 \mathrm{~h}$ at $90 \mathrm{~V}$ (approximate distance of $5 \mathrm{~cm}$ from wells) using a Fluorochem 8800 Image System (Alpha Innotech Corp., San Leandro, CA).

Real-time PCR amplifications were run using a 96-well optical reaction plate in an ABI Prism 7000 Sequence detection system. Thermal cycling conditions were as previously described for conventional PCR. Reaction volumes of $50 \mu \mathrm{l}$ were used containing: $13.4 \mu \mathrm{l}$ sterile $\mathrm{ddH}_{2} \mathrm{O}, 25 \mu \mathrm{l}$ TaqMan universal master mix (Applied Biosystems, cat. no. 4304437), $0.3 \mu \mathrm{l}$ of each forward and reverse primer $(300 \mathrm{nM})$, $1.0 \mu \mathrm{l}$ TaqMan probe $(200 \mathrm{nM})$, and $10 \mu \mathrm{l}$ DNA template.

TaqMan primer and probe design and specificity. TaqMan Primers (forward, 5'GGC TGC GGA ATA GTT GAT TTT GTA C; reverse, 5'-CCA CGG TGG AGA TGC TAT AAG) and Probe (5'-ATC ATT GCG CTC ATT CC) were designed based on a $P$. coronata var. lolii random amplified polymorphic DNA (RAPD) fragment (NCBI accession: AJ537434). The primers were tested for specificity on the $P$. triticina isolate, the $P$. graminis $\mathrm{f}$. sp. avenae isolate, five $P$. coronata isolates, and uninfected oat tissue using conventional PCR. Additionally, probe specificity was tested on the $P$. triticina isolate, the $P$. graminis $\mathrm{f}$. sp. avenae isolate, and one $P$. coronata isolate using real-time PCR.

Real-time PCR assay. To test the consistency of DNA extractions, five inde- 
pendent preparations were made using $10^{5}$, $10^{4}, 10^{3}$, and $10^{2} \mu \mathrm{g}$ of $P$. coronata urediniospores. Additionally, the influence of oat tissue and DNA was tested by adding uninfected oat leaves $(1.5 \mathrm{mg})$ to preparations 3 and 5 before DNA extraction. Ct values were measured with real-time PCR when the magnitude of change in fluorescence between two cycles $(\Delta \mathrm{Rn})$ was 0.1 (within the log phase of all reactions). Standard deviations were calculated and means were compared among preparations within each weight (JMP, SAS Institute).

A standard curve was constructed to calculate FDNA associated with infected oat tissues using real-time PCR. DNA was extracted from $10^{5} \mu \mathrm{g}$ of urediniospores and serially diluted into stock solutions $\left(1.58 \times 10^{5}, 1.58 \times 10^{4}, 1.58 \times 10^{3}, 1.58 \times\right.$ $10^{2}$, and $1.58 \times 10 \mathrm{pg}$ ). The DNA concentration of each standard was quantified (ng/ $\mu \mathrm{l})$ using a spectrophotometer, the samples diluted, and approximately 20 $\mathrm{ng} / \mu \mathrm{l}$ of oat DNA was added to each stock before real-time PCR analysis. To ensure consistency among real-time PCR analyses, aliquots from the original standards were made and stored for later use in each test.

Primary and flag leaves from a single plant $(n=8)$ of each of the five genotypes were inoculated with isolate 98MNB245 in two experiments. After 10 days for primary leaf studies and 12 days for flag leaf studies, leaves were harvested and standardized inoculated areas of $4.8 \mathrm{~cm}^{2}$ were scanned at 118 dots per $\mathrm{cm}$ for digital analysis (Fig. 1). Following scanning, harvested leaves were lyophilized and weighed before PCR analysis. DLA, including pustules and a portion of the chlorotic area, and pustule density were measured based on the images using the Assess image analysis software (17) with high and low threshold settings of 103 and 60. Total DNA was then extracted, analyzed for quantity and quality, diluted to $60 \mathrm{ng} / \mu \mathrm{l}$, and using realtime PCR, FDNA was extrapolated for each genotype. Data were converted to FDNA/mg of oat tissue and transformed using $\log _{10}$. Analysis of variance was used to test sources of variation between repeated experiments, and experimental means of each genotype were compared using a Tukey-Kramer HSD test $(P=0.05)$ (JMP, SAS Institute).

The time course of fungal development after inoculation was measured in Provena, IA 98822-2, and TAM-O-301 in two greenhouse experiments. Inoculated leaf sections were excised every 2 days from 0 to 10 days postinoculation (DPI). At harvest, samples were placed in tubes and stored at $-80^{\circ} \mathrm{C}$. After all samples were harvested, lyophilized, weighed, and total DNA was extracted, real-time PCR was used to estimate FDNA for each sampling time and genotype. Data were converted to FDNA/mg of oat tissue and transformed $\left(\log _{10}\right)$ before statistical analyses. A Tukey-
Kramer HSD test $(P=0.05)$ was used to compare means within each sample time, and linear regression of FDNA versus DPI for each genotype was done (JMP, SAS Institute).

\section{RESULTS}

Inoculum application. To evaluate the consistency of hand held spray inoculation and direct swab inoculation, two experiments were done based on DLA in targeted areas. Ten days after inoculation in both experiments using the direct swab technique, the susceptible Provena had significantly higher DLA than the moderately resistant IA 98822-2, which had significantly higher DLA than the resistant TAMO-301 (Table 1). In the first experiment using spray inoculation, there were no significant differences in DLA between genotypes, while Provena had significantly higher DLA than IA 98822-2 and TAM-O301 in the second experiment. Additionally, standard deviations were higher using hand held spray inoculation from all genotypes in both experiments with the exception of IA 98822-2 in the second experiment (Table 1). The direct swab technique was more consistent, as measured by DLA in a target leaf segment, than hand held spray inoculation and thus was used in the quantitative assay.

Primer and probe specificity. The effectiveness of a PCR-based assay for plant disease is dependent on the specificity of the DNA primers for the pathogen. In this study, we designed a TaqMan primers/probe set to amplify a 75-bp fragment in $P$. coronata, and tests were done to examine the specificity of the primers on DNA templates from uninfected oat and five isolates of $P$. coronata. The expected 75-bp band was visualized only in the $P$. coronata isolates (data not shown). Additionally, tests were done on DNA from isolates of $P$. coronata, $P$. graminis $\mathrm{f}$. $\mathrm{sp}$. avenae, and $P$. triticina using real-time PCR. Real-time PCR amplifications
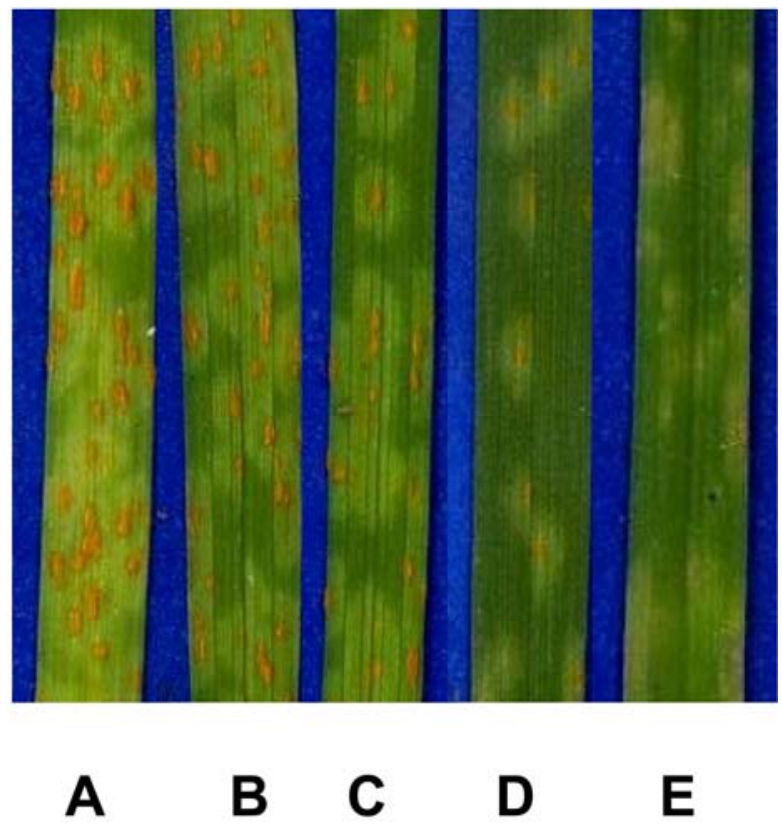

Fig. 1. Leaf samples of Provena (A), Ogle (B), IA98822-2 (C), O $\times$ T 107 (D), and TAM-O-301 (E) infected with Puccinia coronata f. sp. avenae 10 days after inoculation.

Table 1. Mean diseased leaf area (DLA) and standard deviations (SD) from digital assessments of flag leaves from three genotypes inoculated with a single race of Puccinia coronata using two different techniques in two greenhouse experiments ${ }^{\mathrm{z}}$

\begin{tabular}{|c|c|c|c|c|c|}
\hline \multirow[b]{2}{*}{ Inoculation technique } & \multirow[b]{2}{*}{ Genotype } & \multicolumn{2}{|c|}{ Experiment 1} & \multicolumn{2}{|c|}{ Experiment 2} \\
\hline & & $\operatorname{DLA}(\%)$ & SD & DLA $(\%)$ & SD \\
\hline Spray Soltrol 170 & $\begin{array}{l}\text { Provena } \\
\text { IA 98822-2 } \\
\text { TAM-O-301 } \\
\text { (HSD) }\end{array}$ & $\begin{array}{l}9.2 \mathrm{~A} \\
6.8 \mathrm{~A} \\
1.2 \mathrm{~A} \\
8.1\end{array}$ & $\begin{array}{l}5.1 \\
4.9 \\
0.9\end{array}$ & $\begin{array}{c}18.6 \mathrm{~A} \\
7.9 \mathrm{~B} \\
3.6 \mathrm{~B} \\
6.2\end{array}$ & $\begin{array}{l}5.0 \\
1.0 \\
1.7\end{array}$ \\
\hline Swab & $\begin{array}{l}\text { Provena } \\
\text { IA 98822-2 } \\
\text { TAM-O-301 } \\
\text { (HSD) }\end{array}$ & $\begin{array}{c}22.5 \mathrm{~A} \\
7.1 \mathrm{~B} \\
0.0 \mathrm{C} \\
3.0\end{array}$ & $\begin{array}{l}2.2 \\
2.1 \\
0.0\end{array}$ & $\begin{array}{c}15.0 \mathrm{~A} \\
5.4 \mathrm{~B} \\
0.1 \mathrm{C} \\
2.8\end{array}$ & $\begin{array}{l}2.2 \\
1.8 \\
0.1\end{array}$ \\
\hline
\end{tabular}

${ }^{\mathrm{z}}$ Mean DLA and SD were based on digital assessments of five leaves for each inoculation technique and experiment using the Assess imaging software (17). Means followed by different letters within columns and inoculation techniques are significantly different $(P=0.05$, Tukey-Kramer HSD). 
showed that the $\mathrm{Ct}$ of the reaction containing $P$. coronata template DNA was 25.8 cycles at a $\Delta \mathrm{Rn}$ of 0.1 , whereas the $\mathrm{Ct}$ values of the reactions containing $P$. graminis f. sp. avenae and $P$. triticina were undetectable (Fig. 2A). PCR products from each reaction were visualized on agarose gel after 40 cycles. A single band of approximately $75 \mathrm{bp}$ was amplified in the reaction containing the $P$. coronata DNA template, while no amplification was visualized in reactions containing DNA tem- plates from both $P$. graminis f. sp. avenae and $P$. triticina (Fig. 2B). Thus, the TaqMan primers/probe set developed appears to be specific to $P$. coronata and does not amplify DNA from the host Avena sativa, $P$. graminis $\mathrm{f}$. sp. avenae, or $P$. triticina.

DNA extraction protocol and development of a standard curve. Initial experiments testing the consistency of an open tube (mortar and pestle) and a closed tube (vibrator mill) extraction protocol on

\section{A}

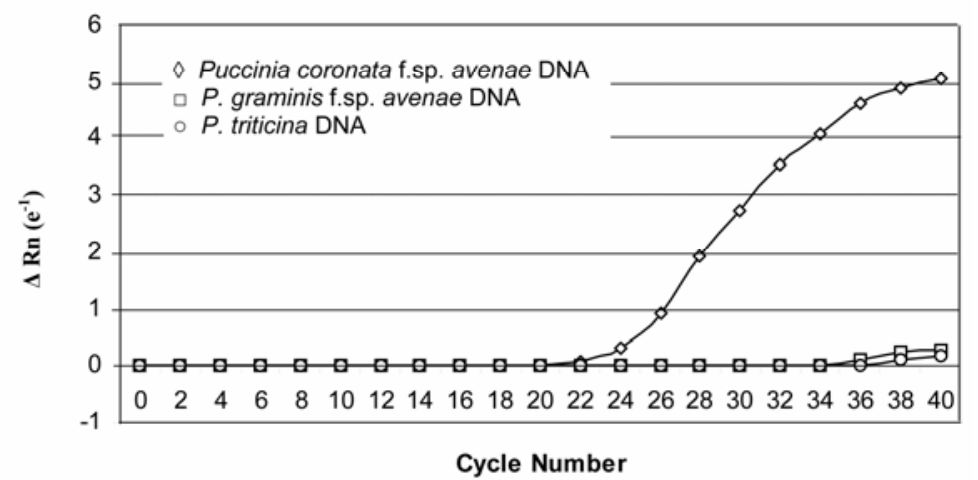

B

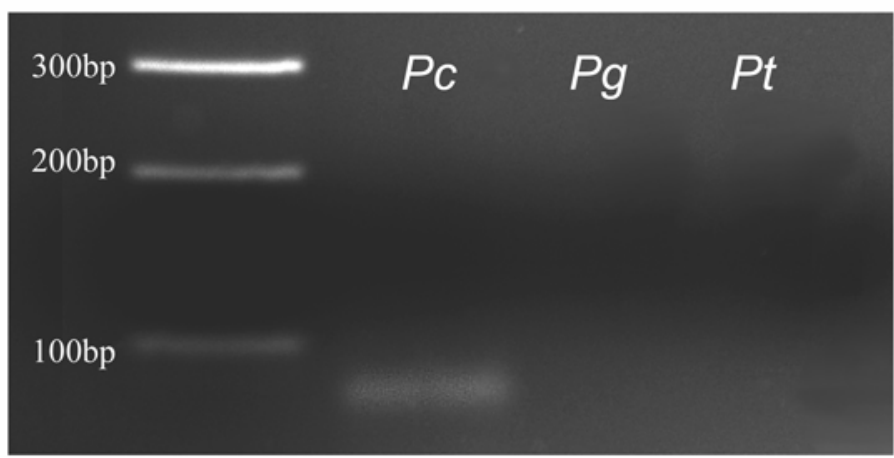

Fig. 2. Specificity to Puccinia coronata of a TaqMan primers/probe set using real-time polymerase chain reaction (PCR) analysis. A, Assessment of probe specificity by real-time PCR amplification profiles of $P$. coronata, $P$. graminis f. sp. avenae, or $P$. triticina $\mathrm{DNA}$. $\Delta \mathrm{Rn}$ values are those representing a difference in fluorescence intensity. B, Assessment of primer specificity by real-time PCR product visualization from reactions containing $P$. coronata $(P c), P$. graminis f. sp. avenae $(P g)$, or $P$. triticina $(P t)$ DNA.

Table 2. Cycle threshold values from real-time polymerase chain reaction (PCR) of different fungal weights over five independent DNA preparations from separate spore increases

\begin{tabular}{lcccccccc}
\hline \multirow{2}{*}{$\begin{array}{l}\text { Fungal } \\
\text { weight }(\boldsymbol{\mu g})\end{array}$} & $\mathbf{1}$ & $\mathbf{2}$ & $\mathbf{3}$ & $\mathbf{4}$ & $\mathbf{5}$ & & Mean $^{\mathbf{z}}$ & SD \\
\cline { 2 - 6 } & 26.7 & 26.4 & 27.5 & 26.0 & 26.7 & $26.6 \mathrm{D}$ & 0.51 \\
$10^{5}$ & 29.1 & 29.0 & 29.4 & 29.9 & 30.0 & $29.5 \mathrm{C}$ & 0.51 \\
$10^{4}$ & 32.8 & 32.5 & 32.7 & 32.2 & 33.5 & $32.7 \mathrm{~B}$ & 0.53 \\
$10^{3}$ & 36.5 & 37.0 & 35.5 & 35.8 & 37.8 & $36.5 \mathrm{~A}$ & 0.91 \\
$10^{2}$ & Undet. & $\ldots$ & $\ldots$ & $\ldots$ & $\ldots$ & $\ldots$ & $\ldots$ \\
0 & & $\ldots$ & & $\ldots$
\end{tabular}

y DNA was prepared from pre-weighed urediniospores of Puccinia coronata collected from five different spore increases. DNA preparations 3 and 5 were made with $1.5 \mathrm{mg}$ of clean oat leaf tissue. Undet. $=$ samples where no signal was detectable.

${ }^{\mathrm{z}}$ Means followed by different letters are significantly different $(P=0.05$, Tukey-Kramer HSD).

sporulating leaves showed that only the closed tube extraction produced consistent results (data not shown). Therefore, the closed tube extraction was used for the assay. The mean $\mathrm{Ct}$ values of urediniospores from five independent extractions were significantly different between weights $(P=0.05$, Tukey-Kramer HSD) and the differences corresponded to the initial urediniospore weights (Table 2). Standard deviations around the mean $\mathrm{Ct}$ values for each of the three highest fungal weights $\left(10^{5}, 10^{4}\right.$, and $\left.10^{3} \mu \mathrm{g}\right)$ were low $(\leq 0.5)$, whereas the standard deviation was higher (0.9) for the lowest weight (Table 2 ). The no-template control remained at the baseline throughout the 40 cycles, and therefore no $\mathrm{Ct}$ was recorded. Furthermore, the addition of uninfected oat leaves to preparations 3 and 5 before extractions did not affect the results (Table 2). These data indicate that the DNA preparation method was consistent and the $\mathrm{Ct}$ values generated by real-time PCR for fungal weights were reproducible.

Since the amplification profiles produced reliable results over multiple DNA preparations, a standard curve was developed to extrapolate values for FDNA associated with infected oat tissues. Amplification profiles from replicated analyses showed that each stock solution ranging from the $1.58 \times 10^{5} \mathrm{pg}$ solution to the 1.58 $\times 10 \mathrm{pg}$ solution had mean $\mathrm{Ct}$ values from 25 to 39 cycles at a $\Delta \mathrm{Rn}$ of 0.1 , respectively (Fig. 3). Standard deviations from the mean of each stock solution were low ( 0.2 to 0.5$)$; therefore aliquots were made from each solution and stored for use as standards to convert unknowns and as internal controls for comparisons of future analyses. These data indicate that the standard curve should provide an adequate conversion of $\mathrm{Ct}$ values from amplified total DNA templates of infected oat tissues to FDNA.

Digital image analysis compared with real-time PCR measurements. In two separate experiments per leaf stage, results from the quantitative assay using real-time PCR were compared with results from digital assessments of primary and flag leaves from the five genotypes. Analysis of variance was done using a fixed model with the sources of variation being genotype, pots within experiment, experiment, and genotype $\times$ experiment for both leaf stages (Table 3). In both leaf stages, genotype was the most significant source of variation for all three assessment parameters: FDNA/mg of oat tissue, pustule density, and DLA $(P<0.0001)$. Experimental variation was significant when assessing DLA of primary leaves and when assessing pustule density and FDNA of flag leaves. Genotype $\times$ experiment variation was slightly significant when assessing FDNA of flag leaves (0.0333). This interaction can be explained by Ogle having less FDNA in experiment 1 than Provena, while the oppo- 
site occurred in experiment 2. Data from experiments were combined for each leaf stage (Table 4), since this did not change the overall interpretation of the data.

At the primary leaf stage, the susceptible genotype Provena had significantly higher mean DLA, pustule density, and FDNA/mg of oat tissue than all other genotypes tested, and both Provena and Ogle showed the highest values for these parameters at the flag leaf stage (Table 4). Mean DLA and pustule density did not significantly differ between Ogle and IA98822-2 as seedlings, but FDNA/mg of oat tissue estimations indicated that fungal infection in Ogle was greater. Similarly, at both leaf stages, the moderately resistant genotype $\mathrm{O} \times \mathrm{T} 107$ had greater fungal infection than TAM-O-301 based on FDNA/mg of oat tissue, whereas these two genotypes did not differ based on pustule density and DLA (Table 4).

Fungal development within genotypes with different levels of resistance. To study the development of $P$. coronata after inoculation, FDNA/mg of oat tissue was estimated with the new assay in resistant (TAM-O-301), moderately resistant (IA98822-2), and susceptible (Provena) genotypes in two experiments. Analysis of variance indicated that the only significant source of variation was genotype $(P=$ $0.0048)$; therefore data from both experiments were combined before analysis. With the new assay, the initial (time $=0$ ) FDNA/mg of oat tissue from TAM-O-301 (0.008 pg), IA 98822-2 (0.006 pg), and Provena $(0.007 \mathrm{pg})$ were not significantly different $(P=0.05$, Tukey-Kramer HSD). At 2 DPI, FDNA/mg of oat tissue measured in Provena was significantly higher than in TAM-O-301 and IA98822-2, and at 4 DPI, IA98822-2 showed significantly greater FDNA/mg of oat tissue than TAMO-301 (Fig. 4A). Regression analyses were done on FDNA/mg of oat tissue by DPI for each genotype. The data significantly fit the predicted lines (TAM-O-301, $R^{2}=$ 0.61 ; IA98822-2, $R^{2}=0.85$; Provena, $R^{2}=$ 0.90 ) and showed that FDNA developed faster in Provena than in IA98822-2 and TAM-O-301, and developed faster in IA98822-2 than in TAM-O-301 (Fig. 4B).

\section{DISCUSSION}

Cereal rust diseases, including crown rust of oat, involve complex host-pathogen interactions $(4,11)$. The complexities of these interactions make defining resistance difficult $(5,18)$. Interactions between cereal crops and rust pathogens have been studied using visual and digital assessments $(8,24,27)$, and although these methods have been useful, they are limited in that they only indirectly measure the presence of the pathogen by assessing symptoms and signs of disease. Since quantification by real-time PCR directly estimates FDNA from total DNA extracted, it provides a new tool for the study of the hostpathogen interaction. Using this tool, we have developed an assay that can effectively estimate DNA of $P$. coronata associated with infected oat tissues.

Previous studies have indicated the importance of primer and probe specificity when developing real-time PCR-based assays $(15,28)$. In our study, we designed a TaqMan primers/probe set for greater specificity compared with oligonucleotide primers. Our results showed that the primers/probe set was specific to five $P$. coro-

A

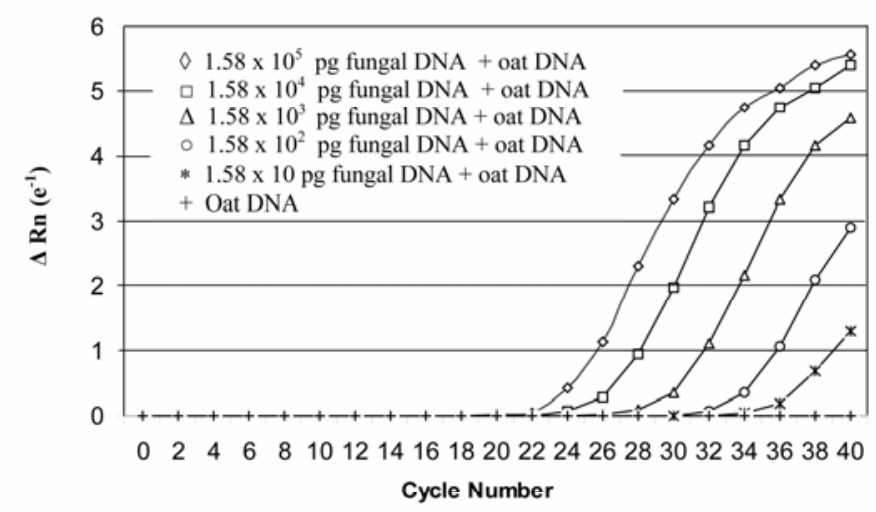

B

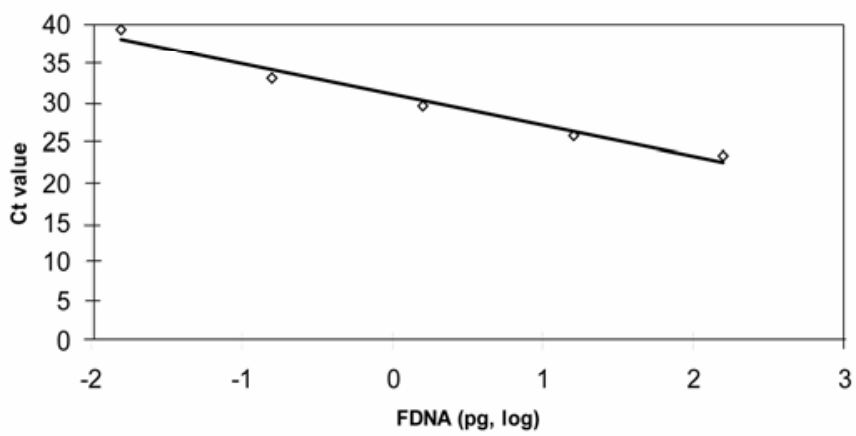

Fig. 3. Standard curve for fungal DNA (FDNA). A, Amplification profiles from 10-fold dilution aliquots of Puccinia coronata DNA $\left(1.58 \times 10^{5} \mathrm{pg}\right)$, extracted from $10^{5} \mu \mathrm{g}$ of urediniospores. $\Delta \mathrm{Rn}$ values are those representing a difference in fluorescence intensity at a given cycle number. B, Standard curve for conversion of cycle threshold $(\mathrm{Ct})$ into FDNA $\left(y=-3.9158 x+31.14, R^{2}=0.99\right)$.

Table 3. Analyses of variance summaries of diseased leaf area (DLA), pustule density, and fungal DNA estimates (FDNA) of three oat genotypes with varying levels of resistance at two leaf stages ${ }^{\mathrm{z}}$

\begin{tabular}{|c|c|c|c|c|c|c|c|c|}
\hline \multirow[b]{2}{*}{ Leaf stage } & \multirow{2}{*}{$\begin{array}{l}\text { Source of } \\
\text { variation }\end{array}$} & \multirow[b]{2}{*}{ df } & \multicolumn{2}{|c|}{ DLA } & \multicolumn{2}{|c|}{ Pustule density $\left(\mathrm{cm}^{2}\right)$} & \multicolumn{2}{|c|}{ FDNA } \\
\hline & & & MS & $P$ & MS & $P$ & MS & $P$ \\
\hline \multirow[t]{5}{*}{ Primary } & Genotype & 4 & 4.09 & $<0.0001$ & 119.89 & $<0.0001$ & 3.27 & $<0.0001$ \\
\hline & Pot[Exp] & 8 & 0.41 & 0.1356 & 5.91 & 0.4769 & 0.23 & 0.4150 \\
\hline & Exp & 1 & 1.26 & 0.0283 & 5.28 & 0.3588 & 0.02 & 0.7644 \\
\hline & Genotype $\times$ Exp & 4 & 0.39 & 0.1930 & 6.11 & 0.4206 & 0.52 & 0.0666 \\
\hline & Error & 32 & 0.24 & & 6.09 & & 0.21 & \\
\hline \multirow[t]{5}{*}{ Flag } & Genotype & 4 & 7.80 & $<0.0001$ & 637.23 & $<0.0001$ & 18.65 & $<0.0001$ \\
\hline & Pot[Exp] & 8 & 0.07 & 0.8852 & 49.87 & 0.3663 & 0.167 & 0.1379 \\
\hline & Exp & 1 & 0.11 & 0.4142 & 431.54 & 0.0037 & 1.23 & 0.0013 \\
\hline & Genotype $\times$ Exp & 4 & 0.06 & 0.8280 & 62.91 & 0.2453 & 0.30 & 0.0333 \\
\hline & Error & 32 & 0.16 & & 43.86 & & 0.10 & \\
\hline
\end{tabular}

${ }^{\mathrm{z}}$ Probability values are based on the corresponding $F$ test. 
nata isolates of different geographic and host-cultivar origin and amplified DNA neither from the host plant, the oat stem rust pathogen, nor the wheat leaf rust pathogen (Fig. 2). Since the primers/probe set does not amplify DNA from the host or other closely related fungi that could be present in oat fields, it will likely be useful for specific detection and quantification of crown rust from field samples. Additional work is needed to test the primers/probe set across more isolates and to develop a TaqMan primers/probe set specific to $P$. graminis f. sp. avenae. Such primers/probe sets could provide an early detection assay of the two oat rust diseases and development of a multiplex assay to simultaneously quantify both crown rust and stem rust.

A QPCR assay is dependent on consistent extraction of DNA from infected tissues and development of a standard curve to convert $\mathrm{Ct}$ values to FDNA (28). Results from five independent extractions of urediniospores in this study indicated that the extraction method produced repeatable results (Table 2). Amplification profiles from repeated analyses of known FDNA standards were also highly reproducible and were used to generate a standard curve (Fig. 3). Valsesia et al. (34) suggested the use of "calibrator DNA" as a way to enable comparisons among results of different QPCR analyses. As internal controls for each assay, they used three $0.2 \mathrm{ng} / \mu \mathrm{l}$ aliquots from the original standard curve dilution series. Results from these aliquots were then used to calibrate a standard curve for each experiment. In the present study, aliquots from all concentrations of the original standard curve dilution series (Fig. 3) were stored at $-20^{\circ} \mathrm{C}$ and used within each test, enabling direct comparisons of data based on the fact that the standards used to calculate unknown samples were identical between tests. In addition, using the stored samples as standards for each test enables slope and intercept comparisons between experiments as another means of checking consistency.

DNA-based tools for detection and quantification are sensitive and consequently can be greatly influenced by the inoculum application method and sampling. Several techniques have been devel- oped to apply rust inoculum uniformly to leaf surfaces including a pneumatic sprayer (1), special spray chambers (31), a spore settling tower (7), and direct application with cotton swabs (14). In our experiments comparing DLA of three genotypes inoculated with oil-based hand-held spray and water-based swab inoculation methods, spores applied with a swab generated the most consistent results (Table 1). This result was similar to that of Hsiang et al. (14), who found more consistent and uniform infection using direct application by cotton swabs versus using spore suspension droplets or dry spore transfers. Additionally, in our study, the direct application method allowed precise application of inoculum to a specific area where disease expression was later measured. Using a similar method, Brodny et al. (6) were able to precisely deposit and distinctly rate different races on the same leaf. Since the swab technique was more consistent than spray applications and allowed precise

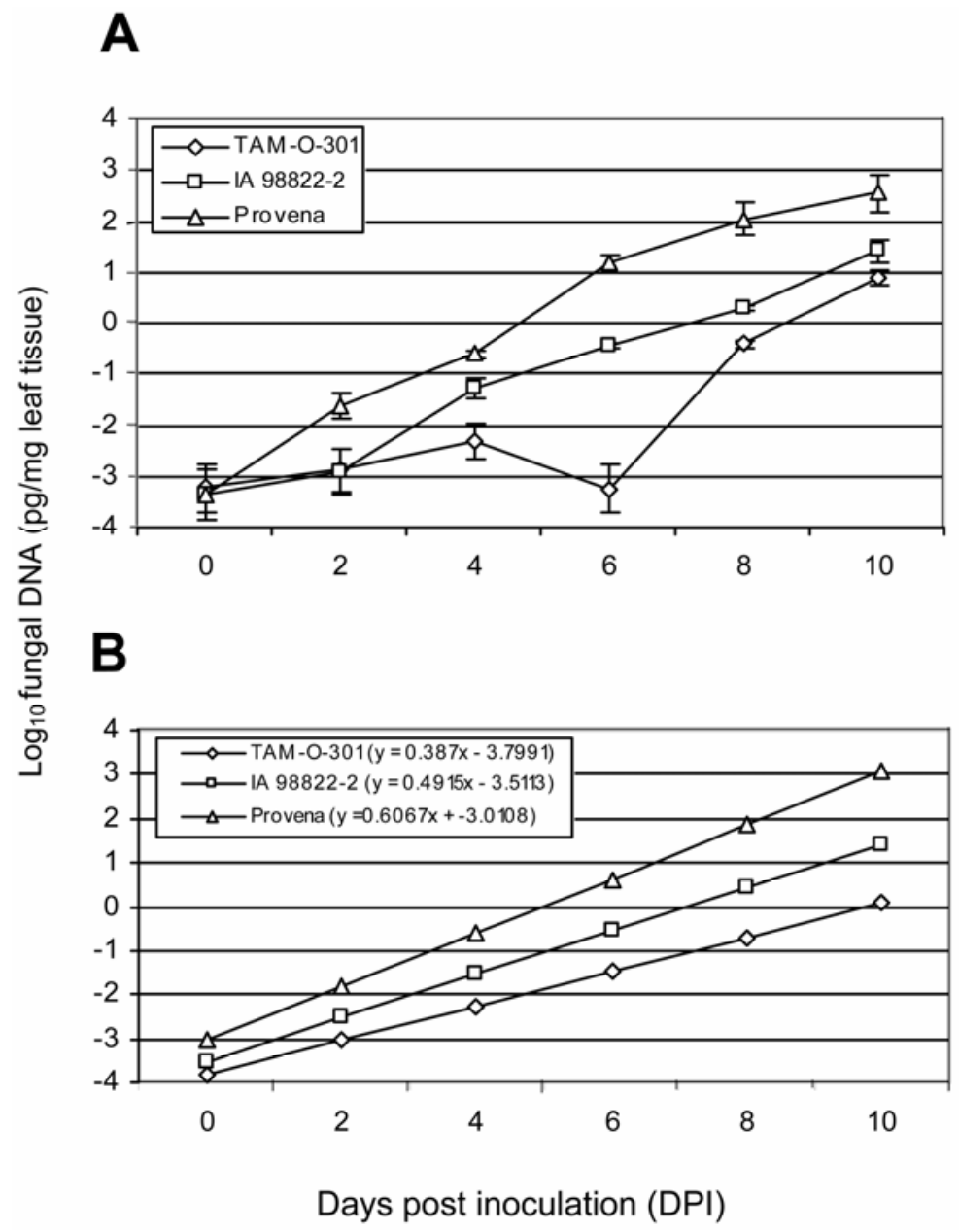

Fig. 4. Growth of Puccinia coronata in seedling leaves of three oat genotypes with different levels of resistance as measured by fungal DNA (FDNA)/mg leaf tissue using real-time polymerase chain reaction (PCR). A, Mean FDNA (pg/mg oat tissue) of P. coronata collected from TAM-O-301, IA98822-2, and Provena 0 to 10 days postinoculation in two combined experiments. B, Regression analysis of FDNA (pg/mg oat tissue) plotted against days postinoculation for TAM-O-301, $R^{2}=0.61$; IA98822-2, $R^{2}=0.85 ;$ and Provena, $R^{2}=0.90$.

Table 4. Mean percent diseased leaf area (DLA), pustule density (pustules $/ \mathrm{cm}^{2}$ ), and fungal DNA (FDNA)/mg of oat tissue from primary and flag leaves of genotypes with varying levels of resistance to Puccinia coronata inoculated in two greenhouse experiments per leaf stage ${ }^{y}$

\begin{tabular}{|c|c|c|c|c|c|c|}
\hline \multirow[b]{2}{*}{ Genotype } & \multicolumn{2}{|c|}{ DLA } & \multicolumn{2}{|c|}{ Pustules/cm ${ }^{2}$} & \multicolumn{2}{|c|}{ FDNA $(\mathrm{pg} / \mathrm{mg} \text { oat tissue })^{\mathrm{z}}$} \\
\hline & Primary & Flag & Primary & Flag & Primary & Flag \\
\hline Provena & $1.5 \mathrm{~A}$ & $1.9 \mathrm{~A}$ & $8.9 \mathrm{~A}$ & $17.3 \mathrm{~A}$ & $686.8 \mathrm{~A}$ & $2290.6 \mathrm{~A}$ \\
\hline Ogle & $0.8 \mathrm{AB}$ & $1.6 \mathrm{~A}$ & $5.3 \mathrm{~B}$ & $17.3 \mathrm{~A}$ & 399.3 B & $1548.5 \mathrm{~A}$ \\
\hline IA98822-2 & $0.6 \mathrm{BC}$ & $0.4 \mathrm{~B}$ & $4.0 \mathrm{BC}$ & $8.6 \mathrm{AB}$ & $97.2 \mathrm{CD}$ & $180.7 \mathrm{~B}$ \\
\hline $\mathrm{O} \times \mathrm{T} 107$ & $0.1 \mathrm{C}$ & $0.1 \mathrm{~B}$ & $2.1 \mathrm{CD}$ & $1.5 \mathrm{~B}$ & $125.4 \mathrm{C}$ & $66.0 \mathrm{C}$ \\
\hline TAM-O-301 & $0.1 \mathrm{C}$ & $0.0 \mathrm{~B}$ & $0.8 \mathrm{D}$ & $1.0 \mathrm{~B}$ & $40.6 \mathrm{D}$ & $1.4 \mathrm{D}$ \\
\hline HSD & 0.7 & 0.5 & 3.1 & 9.4 & & \\
\hline
\end{tabular}

${ }^{y}$ Mean DLA and pustule density were calculated with the Assess image analysis software for plant disease quantification (17). Fungal DNA was estimated

based on real-time PCR using a standard curve. Means within a column followed by different letters are significantly different $(P=0.05)$.

${ }^{\mathrm{z}}$ Significance is based on $\log _{10}$ transformation with an $\mathrm{HSD}=0.4$. 
placement of inoculum onto leaves which could be directly sampled, we chose this method for our quantitative assay. A potential drawback to the direct swab method is the difficulty in measuring inoculum dose, making quantitative application problematic. As previously discussed, inoculations using spore settling towers and pneumatic spray applicators have been shown to be quantitative and reliable. Applying such inoculation methods to our assay could perhaps improve its precision.

Primary and flag leaves of five oat genotypes with varying levels of resistance were assessed using both the new assay and digital image analysis. Fungal infection, measured with the new assay as estimated FDNA content associated with the host, revealed information indiscernible using digital image analysis, including (i) low fungal infection in TAM-O-301 relative to $\mathrm{O} \times \mathrm{T} 107$ at both leaf stages and (ii) higher seedling resistance in IA988222 versus Ogle. Digital assessment software relies on differentiation of color contrast from diseased images, thus differences between software packages can greatly influence data. In our studies, the Assess image analysis software (17) was used. This software does not have the same capabilities in differentiating image color contrasts as software used in previous studies on digital image analysis $(8,27)$. Therefore, further study is needed to compare FDNA estimates from the new assay with more sophisticated digital assessment programs. Another aspect of the quantitative assay is the magnitude of differences between genotypes, which in this study was generally greater than the differences obtained using digital image analysis. Analysis of variance for different assessment methods showed the genotype $x$ experiment interaction was slightly significant only for flag leaf assessment of FDNA (Table 3) but not for the two parameters of digital assessment. This interaction was explained by changes in rank of the two susceptible genotypes. Although the reason for the interaction could not be explained, it highlights the high resolution of the new assay. Therefore, the new assay could improve our ability to identify resistance with smaller effects.

Visual and digital assessments do not measure both sporulation and amount of mycelium below the leaf surface independently, but if samples are collected with care, FDNA/mg of oat tissue as estimated with the new assay will include both of these components. The generally greater differences in FDNA/mg of oat tissue between susceptible and resistant genotypes compared with DLA and pustule density differences indicate that the new assay is in fact a more comprehensive measurement of fungal development in and on the host. The ability to conveniently estimate fungal presence, including sporulation, is valuable because sporulation is a key component of partial resistance. For example, Briẽre and Kushalappa (5) concluded that higher precision in evaluating partial resistance in oat seedlings could be obtained by including the components of spores per leaf and spores per pustule. Future work should examine FDNA/mg of oat tissue estimates from the new assay and their relationship to laborious and variable measurements of sporulation and latent period.

One attribute of QPCR is the ability to measure fungal development before signs or symptoms appear $(9,28)$. Results with the new assay showed that initial inoculum amounts applied to each genotype and measured at 0 DPI were similar over all tests $($ Provena $=0.007$ pg, IA98822-2 = $0.006 \mathrm{pg}$, and TAM-O-301 $=0.008 \mathrm{pg}$ ). Fungal development in the susceptible genotypes progressed faster than in the resistant genotypes. Furthermore, 4 days after inoculation, various levels of fungal development could be differentiated among the resistant genotypes (Fig. 4). These data suggest FDNA estimated by the new assay could be used as a tool to determine differences between genotypes with varying levels of resistance much sooner ( 2 to $4 \mathrm{DPI}$ ) than is possible with conventional methods.

Current QPCR assays for disease have thoroughly established protocols for the real-time PCR component (13). It is unclear, however, if the components of inoculation, sampling, and DNA extraction were evaluated in these studies. Since assays based on molecular tools such as QPCR are highly sensitive, minimizing variability in the other components of the assay is critical. Thus we sought to develop uniform and repeatable inoculation, sampling, and DNA extraction procedures in tandem with the real-time PCR protocol. To our knowledge, this is the first real-time PCR assay for plant disease where the other components are clearly described, and these details should be useful as a basis for future research to develop similar quantitative assays for other cereal rust diseases. Since the assay provides a fast, accurate, and nonbiased measurement of fungal development in the host, future work will explore its usefulness in studies to map quantitative trait loci for partial resistance to crown rust. In addition, the assay could be a valuable research tool for studying other aspects of the host-pathogen interaction.

\section{ACKNOWLEDGMENTS}

We thank Robert Bowden from USDA-ARS Northern Plains Area, Grain Marketing and Production Research Center, Manhattan, KS, and Yue Jin, Marty Carson, and Gerald Ochocki from USDAARS Cereal Disease Laboratory (CDL), St. Paul, $\mathrm{MN}$, for technical information and isolates used in this study. We also thank Dave Hoffman for providing seed of the RIL $\mathrm{O} \times \mathrm{T} 107$. We thank Patrick Fenn, Gene Milus, Y. Yang, and Sam Markell at the University of Arkansas, Department of Plant Pathology, for their technical advice.

\section{LITERATURE CITED}

1. Andres, M. W., and Wilcoxson, R. D. 1984. A device for uniform deposition of liquidsuspended urediospores on seedling and adult cereal plants. Phytopathology 74:550-552.

2. Bates, J. A., Taylor, E. J. A., Kenyon, D. M., and Thomas, J. E. 2001. The application of real-time PCR to the identification, detection and quantification of Pyrenophora species in barley seed. Mol. Plant Pathol. 2(1):49-57.

3. Bonman, J. M., Barnett, R. D., Chong, M. J., Harrison, S. A., Herrington, R., Jannink, J., McMullen, M. S., Obert, D. E., Shaner, G., and Stuthman, D. D. 2004. Multi-location testing to identify oat germplasm with partial resistance to crown rust. Pages 177-178 in: 7th Oat Int. Conf. Proc. P. Peltonen-Sainio and $\mathrm{M}$. Topi-Hulmi, eds. Mtt Agrifood Research Finland, Jokioinen, Finland.

4. Brake, V. M., and Irwin, J. A. G. 1992. Partial resistance of oats to $P$. coronata f.sp. avenae. Aust. J. Agric. Res. 43:1217-1227.

5. Briẽre, S. C., and Kushalappa, A. C. 1995. Evaluation of components of resistance in oat breeding lines and cultivars to crown rust (Puccinia coronata f. sp. avenae) under controlled environmental conditions. Can. J. Plant Pathol. 17:319-324.

6. Brodny, U., Briggle, L. W., and Wahl, I. 1976. Reaction of U.S. crown rust resistant oat selections and Israeli Avena sterilis selections to Puccinia coronata var. avenae. Plant Dis. Rep. 60:902-906.

7. Brown, J. F., and Kochman, J. K. 1973. A spore settling tower for quantitative inoculation of leaf blades of mature small grain plants with urediospores. Aust. Plant Pathol. Soc. Newsl. 2:26.

8. Diaz-Lago, J. E., Stuthman, D. D., and Leonard, K. J. 2003. Evaluation of components of partial resistance to oat crown rust using digital image analysis. Plant Dis. 87:667-674.

9. Gao, X., Jackson, T. A., Lambert, K. N., Li, S., Hartman, G. L., and Niblack, T. L. 2004. Detection and quantification of Fusarium sonlani f. sp. glycines in soybean roots with real-time quantitative polymerase chain reaction. Plant Dis. 88:1372-1380.

10. Harder, D. E., and Haber, S. 1992. Oat diseases and pathological techniques. Pages 307 425 in: Oat Science and Technology. H. G. Marshall and M. E. Sorrells, ed. American Society of Agronomy, Madison, WI.

11. Heagle, A. S., and Moore, M. B. 1970. Some effects of moderate adult resistance to crown rust of oats. Phytopathology 60:461-466.

12. Heild, C. A., Stevens, J., Livak, K. L., and Williams, P. M. 1996. Real time quantitative PCR. Genome Methods 6:986-994.

13. Henson, J. M., and French, R. 1993. The polymerase chain reaction and plant disease diagnosis. Annu. Rev. Phytopathol. 31:81-109.

14. Hsiang, T., Cook, S., and Zhao, Y. 2004. Studies on biology and control of daylily rust in Canada. Daylily J. 59(1):47-57.

15. Judelson, H. S., and Tooley, P. W. 2000. Enhanced polymerase chain reaction methods for detecting and quantifying Phytophthora infestans in plants. Phytopathology 90:11121119.

16. Kreimer, D. I., and Nufert, T. H. 1999. Advances in the direct detection of analytes in mixtures using optical spectroscopy as applied to and stimulated by molecular biology and biotechnology. J. Mol. Biol. Biotechnol. 1:416.

17. Lamari, L. 2002. Assess image analysis software for plant disease quantification. American Phytopathological Society, St Paul MN.

18. Milus, E. A., and Line, R. F. 1980. Characterization of resistance to leaf rust in Pacific Northwest wheats. Phytopathology 70:167 172.

19. Murphy, H. C., Stanton, T. R., and Coffman, F 
A. 1942. Breeding for disease resistance in oats. Agron. J. 34:72-89.

20. Nutter, F. W., Jr., Gleason, M. L., Jenco, J. H., and Christians, N. C. 1993. Assessing the accuracy, intra-rater repeatability, and inter-rater reliability of disease assessment systems. Phytopathology 83:806-812.

21. Ohm, H. W., and Shaner, G. E. 1976. Three components of slow leaf-rusting at different growth stages in wheat. Phytopathology 66:1356-1360.

22. Parlevliet, J. E. 1985. Resistance of the nonrace-specific type. Pages 501-525 in: The Cereal Rusts, Vol. II. A. P. Roelfs and W. R. Bushnell, eds. Academic Press, New York.

23. Parlevliet, J. E. 1986. Pleiotropic association of infection frequency and latent period of two barley cultivars partially resistant to barley leaf rust. Euphytica 35:267-272.

24. Peterson, R. F., Campbell, A. B., and Hannah, A. E. 1948. A diagrammatic scale for estimating rust intensity on leaves and stems of cereals. Can. J. Res. 26:496-500.
25. Politowski, K., and Browning, J. A. 1974. The effect of temperature, light, and dew duration on the development of infection structures of Puccinia coronata avenae. Phytopathology 65:1400-1404.

26. Portyanko, V. A., Hoffman, D. L., Lee, M., and Holland, J. B. 2001. A linkage map of hexaploid oat based on grass anchor DNA clones and its relationships to other oat maps. Genome 44:249-265.

27. Price, T. V., Gross, R., Ho Wey, J., and Osborne, C. F. 1993. A comparison of visual and digital image-processing in quantifying the severity of coffee leaf rust (Hemilea vastatrix). Aust. J. Exp. Agric. 33:97-101.

28. Qi, M., and Yang, Y. 2002. Quantification of Magnaporthe grisea during infection of rice plants using real-time polymerase chain reaction and northern blot/phosphoimaging analyses. Phytopathology 92:870-876.

29. Robert, C., Bancal, M.-O., and Lannou, C. 2004. Wheat leaf rust uredospore production on adult plants: Influence of leaf nitrogen con- tent and Septoria tritici blotch. Phytopathology 94:712-721.

30. Roelfs, A. P. 1988. Genetic control of phenotypes in wheat stem rust. Annu. Rev. Phytopathol. 26:351-367.

31. Rowell, J. B., and Olien, C. R. 1957. Controlled inoculation of wheat seedlings with urediospores of Puccinia graminis var. tritici. Phytopathology 47:650-655.

32. Simons, M. D. 1954. The relationship of temperature and stage of growth to the crown rust reaction of certain varieties of oats. Phytopathology 44:221-224.

33. Simons, M. D. 1985. Crown rust. Pages 131-172 in: The Cereal Rusts, Vol. II. A. P. Roelfs and W. R. Bushnell, eds. Academic Press, New York.

34. Valsesia, G., Gobbin, D., Patocchi, A., Vecchione, A., Pertot, I., and Gessler, C. 2005. Development of a high-throughput method for quantification of Plasmopara viticola DNA in grapevine leaves by means of quantitative realtime polymerase chain reaction. Phytopathology 95:672-678. 